\title{
MODELING POINT AND NON-POINT NUTRIENT FLUXES IN RIVER SYSTEMS OF LAKE PEIPSI DRAINAGE BASIN
}

\author{
Kristjan Piirimäe \\ Tallinn Technical University, Estonia
}

\begin{abstract}
$\mathrm{N}$ and $\mathrm{P}$ compounds work as key elements causing bioproduction and eutrophication in water bodies of the Baltic Sea region. A large-scale dynamic GIS-embedded PolFlow model considers all point and diffuse emission sources in a river basin simulating also transport and retention of nutrients in time steps of five years. This modeling approach was originally developed for simulating past and present nutrient loads for the Rhine and Elbe rivers. In addition, a statistical model MESAW was employed for nutrient source apportionment and emission estimations. This paper analysis the modeling results in Lake Peipsi basin, shared by Estonia, Russia and Latvia, for long-term trends since 1985 till 1999. Results of modeling, as well as monitoring data indicate quite stable long-term $P$ load while agricultural $\mathrm{N}$ load has decreased significantly in connection with dramatic changes in agricultural structures. That, in turn, has lead to sharp decrease of N/P ratio in riverine runoff while in lakes (L Peipsi, L Võrtsjärv) and coastal seas, N/P ratio has dropped below 10. These changes, enhancing cyanobacterial blooms, have significantly worsened the ecological state of these water bodies, in the conditions of decreased emissions. The paper concludes that wastewater treatment should focus on better removal of phosphorus.
\end{abstract}

\section{KEYWORDS}

Waste water treatment; Modeling nutrient fluxes; Nutrient source apportionment.

\section{INTRODUCTION}

The nutrient level and fluxes at a specific location in a river network depends on the pollution sources in the upstream area, and the transfer, retention, and loss of nutrients in the soil, groundwater, and surface water network. This is a complex function of biological, physical, and chemical processes.

$\mathbf{N}$ and $\mathbf{P}$ compounds work as key elements causing bioproduction and eutrophication in water bodies of the Baltic Sea region. Formation of water quality status in a river basin depends on natural processes and human activities. The latter influence water quality via 
river basin (cultivation, fertilization, drainage, use of pesticides etc.) and via direct wastewater inputs to water bodies.

Point sources. Pollution load from point sources (industries, municipalities) are relatively easy to measure, control and regulate. Implementation of purification measures enables to significantly reduce pollution load. Large amount of nutrients and the other pollutants are discharged into rivers via direct discharges from coastal settlements, industries and the atmosphere. Many rivers catch municipal and industrial wastewaters. Surface water of the L. Peipsi basin area is also affected by mining activities, fish farming and cooling waters. As a rule, there is a combined sewage system of wastewater treatment in Estonia and in Russia. Both industrial and municipal wastewaters purify in common plants.

Non-point load is caused by human activities or have natural origin. Pollution prevention methods may be the most cost-effective and different, combining various measures. Nonpoint pollution comes from entire river basin area, thus, assessment of its impact is complicated and the reduction of pollution requires a combination of different measures such as legislative, institutional, technical, economical and informational measures. Nutrients, especially nitrogen, originate mostly from non-point sources.

The paper analyses the modeling results in Lake Peipsi basin, shared by Estonia, Russia and Latvia, for long-term trends since 1985 till 1999. The paper also describes nutrient transformation and retention processes in river systems.

\section{MATERIAL AND METHODS}

Study area. Lake Peipsi, is the fourth largest lake in Europe (Fig. 1). The drainage basin is approximately $44000 \mathrm{~km}^{2} ; 36 \%$ in Estonia, $57 \%$ in Russia and $7 \%$ in Latvia. Agricultural land and forests cover $42 \%$ and $40 \%$ of the total drainage basin, respectively. The main focus was on the Estonian part of the drainage basin.

Data. PolFlow model exploited national statistics and research data describing natural conditions, agricultural -activities, sewage treatment, point pollution sources, and demography in the entire drainage basin. Study period for PolFlow was 1985-1999. MESAW model used time series of total- $\mathrm{N}$ and total-P concentrations, point source emissions, atmospheric deposition and data on runoff as well as subwatershed delineation maps. The study period was fixed to 1993-2000 while study area was restricted with Estonian side of the lake Peipsi drainage basin. The main data sources were Estonian national surface water monitoring data, Estonian national point source emission database (provided by the Data and Information Centre of the Estonian Ministry of Environment) as well as Estonian yearbooks of agriculture, environment and demographics, provided by Estonian Statistical Office.

PolFlow model. The changes in nutrient transport under the various scenarios were calculated using a dynamic, GIS-embedded model that simulates nutrient emissions, transport and retention in drainage basins in time steps of five years. This modelling approach was originally developed for simulating past and present nutrient loads for the 
KALMAR ECO-TECH'03

Bioremediation and Leachate Treatment

KALMAR, SWEDEN, November 25-27, 2003

Rhine and Elbe rivers [2,3]. Recently, the model has been implemented for Lake Peipsi/Chudskoe drainage basin [9] using an integrated GIS-database of this region [6,7].

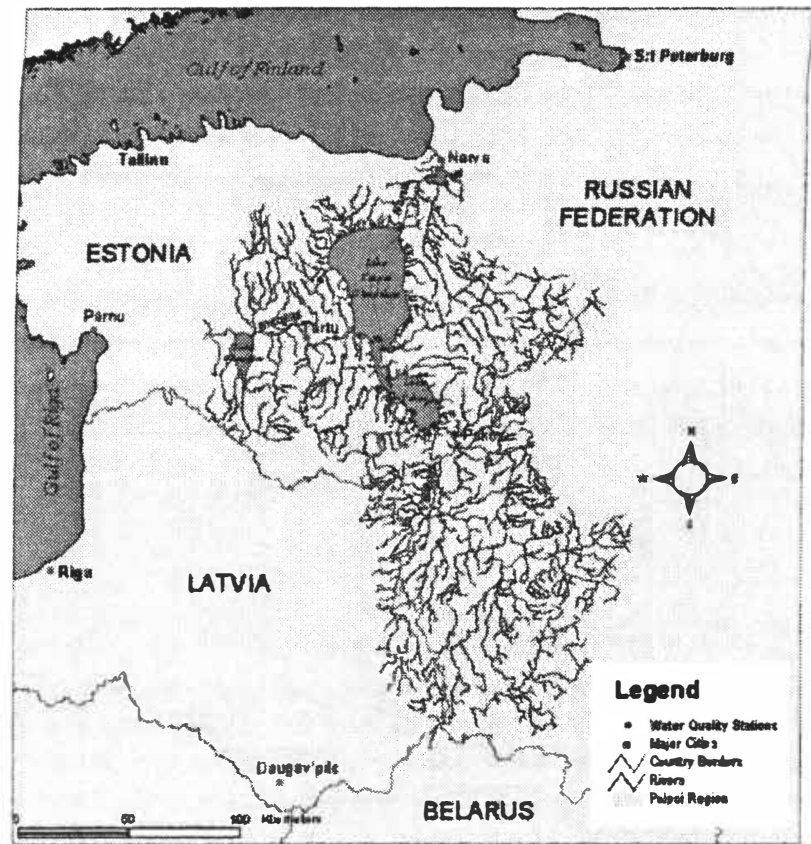

Figure 1. Lake Peipsi and its drainage basin with examples of water quality sites and major cities. Source: Royal Institute of Technology,

Sweden(unpublished).

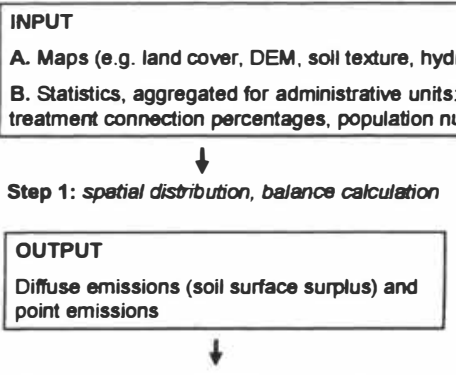

Step 3: routing of nutients through the soil / grounowater system and the river network

$\downarrow$

Figure 2. Overview of the nutrient modelling approach. 
KALMAR ECO-TECH'03

Bioremediation and Leachate Treatment

KALMAR, SWEDEN, November 25-27, 2003

The modelling approach consists of three main steps: 1) Compiling maps of diffuse emissions (soil surface surplus) and point sources emissions from agricultural statistics and a land cover map; 2) Modelling of long-term hydrological fluxes and residence times in the various hydrological compartments ("slow", "medium", and "fast" runoff component); 3) routing the emitted nutrients through the soil/groundwater system and river network in proportion to the long-term hydrological fluxes. The first two steps are static: for each model time step (five year), the procedure is repeated, using the appropriate input data. The third step is dynamic: this means that output from a previous step is used as input for the next step. In this way, the effect of temporary storage of nutrients in the soil/groundwater is accounted for. A more detailed description of the modelling procedure can be found in De Wit [2,3] and in Mourad and Van der Perk [9]. Nutrient loads were calculated for the time period 1985-1999 (3 time steps).

MESAW model. The MESAW-model is a statistical model for source apportionment of the river transport of pollutants [4]. This model-approach uses non-linear regression for simultaneous estimation of source strength (i.e. export coefficients to surface waters) for the different land use or soil categories and retention coefficients for pollutants in a river basin or lakes. The basic principles and major steps in the procedure are as follows: (i) estimation of river loads at each water quality monitoring site (ii) subdivision of the entire drainage basin into subbasins, defined by the monitoring sites for water quality and their upstream-downstream relationships (describing the river system) (iii) derivation of statistics on e.g. land use, soil type, lake area, point source emissions and other relevant data for each subbasin (iv) using a general non-linear regression expression with loads at each subbasin as the dependent/response variable and subbasin characteristics as covariates/explanatory variables. MESAW models have been further detailed in Loigu et al 2001 [8] and Vassiljev \& Stalnacke 2003 [12].

\section{RESULTS AND DISCUSSION}

\subsection{Nutrient source apportionment}

MESAW results. Based on the MESAW model [12], in 1993 more than $60 \%$ of the total nitrogen in the Estonian side of L Peipsi drainage basin originated from agricultural land (Figure 3). Forest contributed with less than $30 \%$ of the nitrogen load. The corresponding results for phosphorus showed that approximately $40 \%$ of the load originated from agricultural land while point sources accounted for approximately $42 \%$. These results resemble well with nutrient source apportionment results in river Warnow with Finnish method $[10,11]$ where as much as $49 \%$ of $\mathrm{P}$ and $18 \%$ of $\mathrm{N}$ were found to originate from point sources.

PolFlow results. For time period 1995 - 1999 in Northem part of Lake Peipsi drainage basin (excluding River Velikaya), only $4 \%$ of $\mathrm{N}$ and $13 \%$ of $\mathrm{P}$ originated from point sources (Figure 3). PolFlow results resemble well with nutrient source apportionment results in river Warnow with German immission model [1] where only $14 \%$ of $\mathrm{P}$ and $6 \%$ of $\mathrm{N}$ were found to originate from point sources [11]. 
KALMAR ECO-TECH'03

Bioremediation and Leachate Treatment

KALMAR, SWEDEN, November 25-27, 2003

These results show that further $\mathrm{N}$ removal from wastewater in L Peipsi basin can not give more than $8 \%$ decrease of $\mathrm{N}$ load in rivers. In the same time, potential effect of better $\mathrm{P}$ removal remains very uncertain. According to this paper, better waste water treatment may remove $13-42 \%$ of total $P$ load in Lake Peipsi drainage basin.
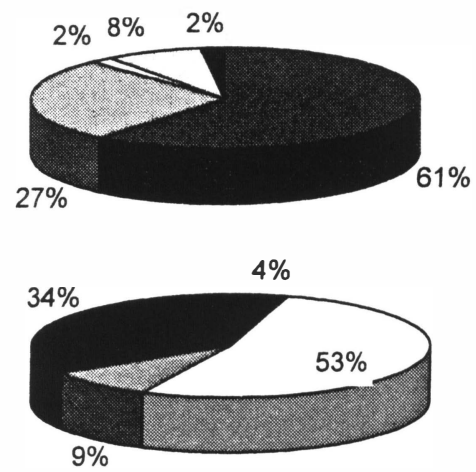

- Agricultural land

\%orest

口Other

口Point sources

Deposition on the lakes

Direct load

口Diffuse load

Background load

Atmospheric load
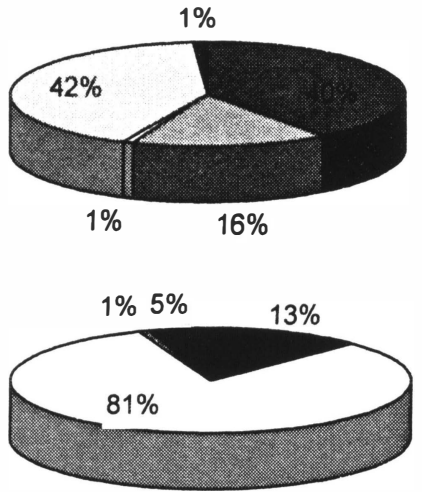

Figure 3. Apportionment of different sources of Nitrogen (left) and Phosphorus (right) load in time period in the Lake Peipsi drainage basin (excluding Velikaya basin) according to MESAW (upper pies) and PolFlow (lower pies) model.

\subsection{Post-communist trends of $\mathbf{N}$ and $P$ in the river basin}

Emissions. The results from the MESAW model runs, which were conducted for each year separately, showed that the unit-area losses of nitrogen and phosphorus from agricultural land varied between $6.9-15 \mathrm{~kg} \mathrm{~N}^{-1}$ and $0.17-0.63 \mathrm{~kg} \mathrm{P} \mathrm{ha}^{-1}$. Interestingly, our estimates corroborate well with the results of monitored losses from a small agricultural catchment (i.e., Oostriku, $29.7 \mathrm{~km}^{2}$ ). In addition, our results showed that the nitrogen losses from agricultural land were almost four times higher than the corresponding losses from forested land.

Total emissions of both $\mathrm{N}$ and $\mathrm{P}$ during the period 1985-1999 decreased considerably (Figure 4). For Estonia and Latvia, P emissions even dropped below zero by the last time period: extraction of $\mathrm{P}$ from arable land was probably larger than the input. 
KALMAR ECO-TECH'03

Bioremediation and Leachate Treatment

KALMAR, SWEDEN, November 25-27, 2003

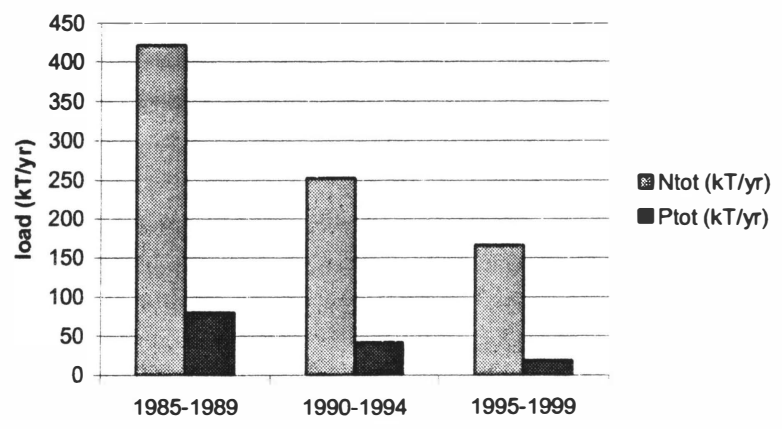

Figure 4. Modelled long-term dynamics of nutrient emissions in Lake Peipsi drainage basin

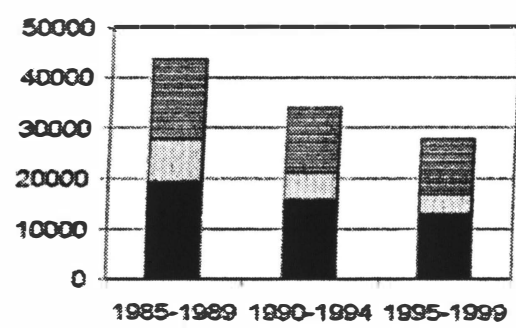

- R Velikaya

母R Emajögi

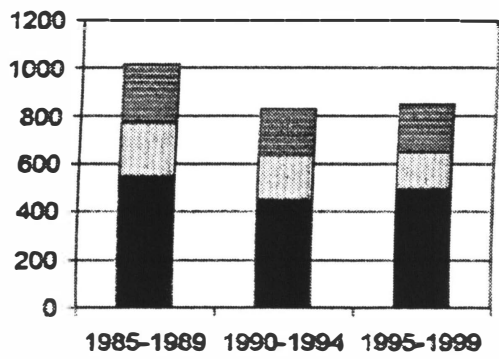

Figure 5. Modelled Nitrogen (left) and Phosphorus (right) load into lake Peipsi (T/yr) 1985-1999.

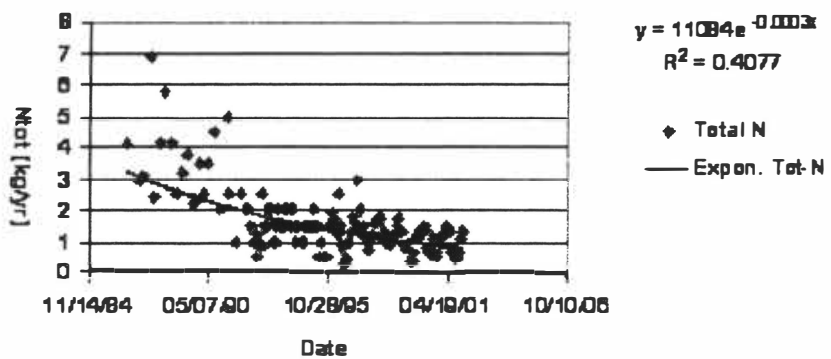

Figure 6. Observed Nitrogen load in R. Võhandu $1984-2001$. 


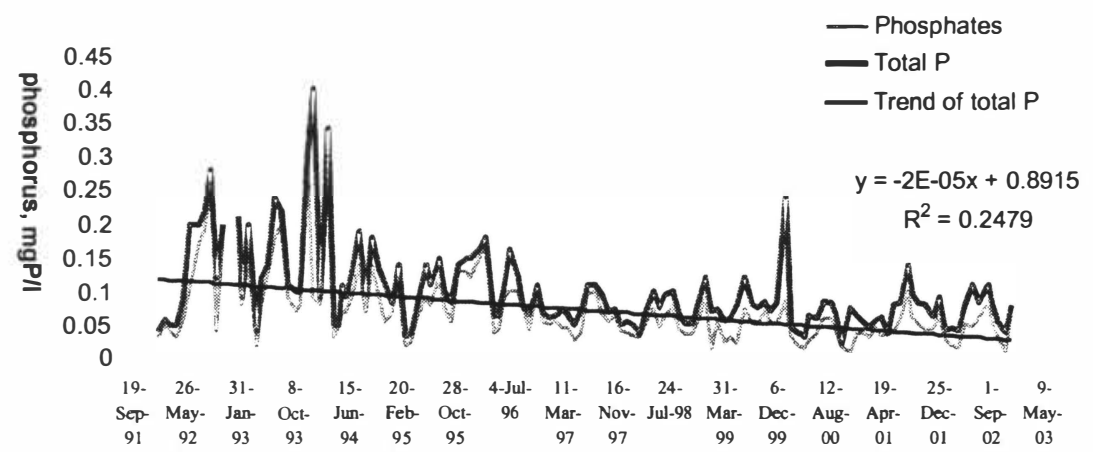

Figure 7. Observed phosphorus concentration in R. Tänassilma 1991-2002.

Loads. Figure 5 shows the simulated Ntot and Ptot loads into Lake Peipsi for the 19851999 period. Ntot loads into the lake have decreased during the nineties. Such results are in well accordance with several monitoring results from Estonian rivers (such as R. Võhandu, Figure 6) where significant long term downward trend of $\mathrm{N}$ loads was detected.

Although P emissions decreased considerably during the study period, P loads did not respond in the same way (Figure 5 right, Figure 7). Instead, modeled P loads increased in the last period, and measured $\mathrm{P}$ loads in several Estonian rivers could not reveal statistically significant downward trends.

$\mathrm{N} / \mathbf{P}$ ratio in rivers. As a result of sharp decrease of $\mathrm{N}$ loads, investigations in Peipsi drainage basin have shown significant decrease of N/P ratio in the beginning of 1990-es. It dropped from 80-100 in 1987 to 12-15 in 1991 (Figure 8). The main reason for that could be agricultural changes in Estonia after the collapse of Soviet Union when the rate of nitrogen fertilization dropped sharply. Another reason could be bad functioning of $P$ removal in the wastewater treatment plants of small settlements. 


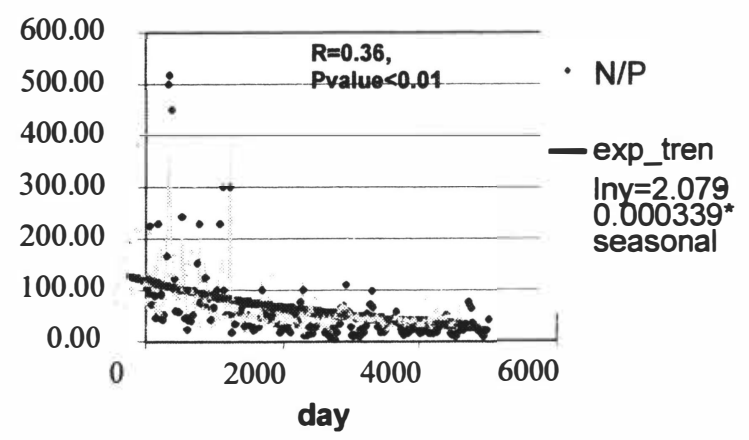

Figure 8. Observed ratio between nitrogen and phosphorus load in $R$. Emajögi since January 1987.

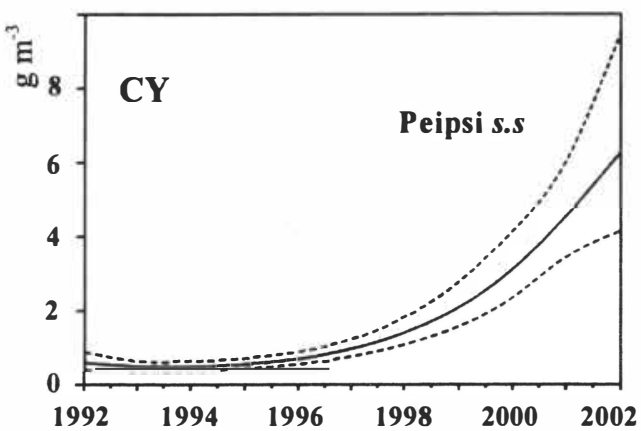

Figure 9. Observed biomass of cyanobacteria in L. Peipsi $1992-2002$ according to Kangur et al. 2002.

Response in L Peipsi. Low N/P ratio can increase probability that in lakes and coastal seas nitrogen will limit primary production instead of phosphorus. Nitrogen limitation in a lake, in turn, may enhance $\mathrm{N}$-fixing cyanobacteria. According to Kangur et al [5], the biomass of cyanobacteria in Lake Peipsi has increased sharply in recent years (Figure 9). Due to that it is important to pay more attention to $\mathrm{P}$ removal in wastewater treatment plants. 


\section{CONCLUSIONS}

Results show that $4-8 \%$ of the nitrogen load to Lake Peipsi originates from wastewater (point pollution sources); approximately $50-60 \%$ of the load comes from agriculture and $30-50 \%$ originates from forests and other diffuse sources. Of the phosphorus load, 13 $40 \%$ come from point pollution sources and $40-80 \%$ from agriculture via the rivers in the catchment area.

The model results suggest that changes in arable land is a major factor controlling nutrient loads to Lake Peipsi. Better wastewater treatment may give significant environmental results in case of $\mathrm{P}$ removal while further $\mathrm{N}$ removal seems almost useless. As N/P ratio in rivers and Lake Peipsi has decreased significantly within post-soviet period, cyanobacterial blooms threaten the aquatic environment of the lake, and coastal sea of Gulf of Finland. The paper concludes that in addition to the reduction of pollutant loads, it is necessary to control also the balance between different pollutants in the environment.

\section{REFERENCES}

[1] Behrendt, H., 1993. Separation of point and diffuse loads of pollutants using monitoring data of rivers. Water Science and Technology 28, 165-175.

[2] De Wit, M., 1999. Nutrient fluxes in the Rhine and Elbe basins. PhD thesis, Faculty of Geographical Sciences, Utrecht University, Netherlands Geographical Studies 259.

[3] De Wit, M.J.M., 2001. Nutrient fluxes at the river basin scale. I: the PolFlow model. Hydrological Processes, 15, 743-759.

DOI: https://doi.org/10.1002/hyp.175

[4] Grimvall, A. and Stålnacke, P., 1996. Statistical methods for source apportionment of riverine loads of pollutants. Environmetrics 7: 201-213.

Kangur, K., Kangur, A., Haberman, J., Haldna, M., Kangur, P., Laugaste, R., Milius, A., Mäemets, H., Möls, T., 2003. 7.1. Water quality assessment. In: Nõges, T. (ed.). Final report on the relevant system of indicators and criteria for evaluating the ecological status of a very large nonstratified lake and its river basin in WFD context. Unpublished.

[5] Langaas, S. (ed.), 2002. MANTRA-East Narva river / Lake Peipsi catchment multi-thematic GIS database. wwwimantraeast.iorg/gis

[6] Langaas, S., Hannerz, F, Nilsson, S., Tian, Y., Jouravkova, O., Tomingas, O., Mourad, D., Vasiliev, A., Skakalsky, B., Stålnacke, P., 2003. The multi-thematic transboundary Narva river / Lake Peipsi catchment GIS database: what, why, how, and beyond. Abstract accepted for the 7th International Conference on Diffuse Pollution and Basin Management, Dublin, 17-22 August 2003.

[8] Loigu, E., Leisk, Ü., Iital, A., Hannus, M., Vassiljev, A., Blinova, I., 2001. Water quality and pollution load of the rivers of the L. Peipsi basin. In: Lake Peipsi Meteorology Hydrology Hydrochemistry. (Ed. By T. Nõges). Tartu 2001, Sulemees, 73-96.

[9] Mourad, D.S.J. and Van der Perk, M., 2002. Modelling nutrient fluxes from diffuse and point emissions to river loads: the Estonian part of the transboundary Lake Peipsi / Chudskoe drainage basin (Russiai/ Estoniai/ Latvia). Proceedings 
KALMAR ECO-TECH'03

Bioremediation and Leachate Treatment

KALMAR, SWEDEN, November 25-27, 2003

6th International Conference on Diffuse Pollution, Amsterdam, 30 September - 4 October 2002, 259-266.

[10] Rekolainen, S., 1989. Phosphorus and nitrogen load from forest and agricultural areas in Finland, Aqua Fennica 19,2, 95-107.

[11] Salo, S., Ekholm, P., and Knuuttila, S., 1997. A comparison of methods for nutrient source apportionment in Nordic rivers. 16-17.

[12] Vassiljev, A., Stålnacke, P., 2003. Source apportionment of nutrients in the Estonian part of the Lake Peipsi drainage basin - experiences from a statistical model. In: Proceedings of Diffuse Pollution and Basin Management Conference (DipCon), Dub 